\title{
The role of bioturbation-driven substrate disturbance in the Mesozoic brachiopod decline
}

\author{
Marko Manojlovic and Matthew E. Clapham (1)
}

\begin{abstract}
Brachiopods dominated the seafloor as a primary member of the Paleozoic fauna. Despite the devastating effects of the end-Permian extinction, the group recovered during the early Mesozoic only to gradually decline from the Jurassic to today. This decline likely had multiple causes, including increased predation and bioturbation-driven substrate disruption, but the role of changing substrate is not well understood. Given the importance of substrate for extant brachiopod habitat, we documented Mesozoic-Cenozoic lithologic preferences and morphological changes to assess how decreasing firm-substrate habitat may have contributed to the brachiopod decline. Compared with bivalves, Mesozoic brachiopods occurred more frequently and were disproportionately abundant in carbonate lithologies. Although patterns in glauconitic or ferruginous sediments are equivocal, brachiopods became more abundant in coarser-grained carbonates and less abundant in fine-grained siliciclastics. During the Jurassic, brachiopod species rarely had abraded beaks but tended to be more convex with a high beak, potentially consistent with a non-analogue lifestyle resting on the seafloor. However, those highly convex morphotypes largely disappeared by the Cenozoic, when more terebratulides had abraded beaks, suggesting closer attachment to hard substrates. Rhynchonellides disproportionately declined to become a minor component of Cenozoic faunas, perhaps because of less pronounced morphological shifts. Trends in lithologic preferences and morphology are consistent with bioturbation-driven substrate disruption, with brachiopods initially using firmer carbonate sediments as refugia before adapting to live primarily attached to hard surfaces. This progressive habitat restriction likely played a role in the final brachiopod decline, as bioturbating ecosystem engineers transformed benthic habitats in the Mesozoic and Cenozoic.
\end{abstract}

Marko Manojlovic and Matthew E. Clapham. Department of Earth and Planetary Sciences, University of California, Santa Cruz, Santa Cruz, California 95064 U.S.A. E-mail: mmanojlo@asu.edu,mclapham@ucsc.edu

Accepted: 25 September 2020

Data available from the Dryad Digital Repository: https://doi.org/10.7291/D1696V

\section{Introduction}

Brachiopods were one of the primary constituents of the Paleozoic Fauna, ecosystems dominated by sessile suspension-feeding organisms rather than the motile gastropods, crustaceans, and infaunal bivalves and echinoids that dominate today's seafloor. The transition from the brachiopod-dominated Paleozoic Fauna to the bivalve-dominated Modern Fauna shaped the taxonomic composition of present-day oceans (Sepkoski 1981) and was part of a shift to more motile taxa and greater energetics in the marine biosphere (Bush et al. 2007; Finnegan et al. 2011; Payne et al. 2014). Though the Paleozoic Fauna was decimated at the end-Permian mass extinction (Gould and Calloway 1980; Fraiser and Bottjer 2007), brachiopods recovered and were locally abundant in communities from the Middle Triassic to Middle Jurassic
(Fig. 1) (Clapham and Bottjer 2007; Greene et al. 2011). However, by the Late Cretaceous and Cenozoic brachiopods were exceedingly rare in most shallow-marine habitats, having undergone a pronounced decrease in abundance during the Late Jurassic and Early Cretaceous (Fig. 1) (Clapham and Bottjer 2007).

The causes of this Late Jurassic and Early Cretaceous brachiopod decline are not well understood, but may have included predation (e.g., Donovan and Gale 1990) and competition with bivalves (Steele-Petrović 1979; Thayer 1985; Liow et al. 2015), as well as increasing bioturbation (Thayer 1979) and grazing pressure (Vermeij 1977; Tomašových 2008). Predation is plausible, as the brachiopod decline coincided with the Mesozoic marine revolution (Vermeij 1977) and brachiopods can be targeted by predators even if they may not be preferred 

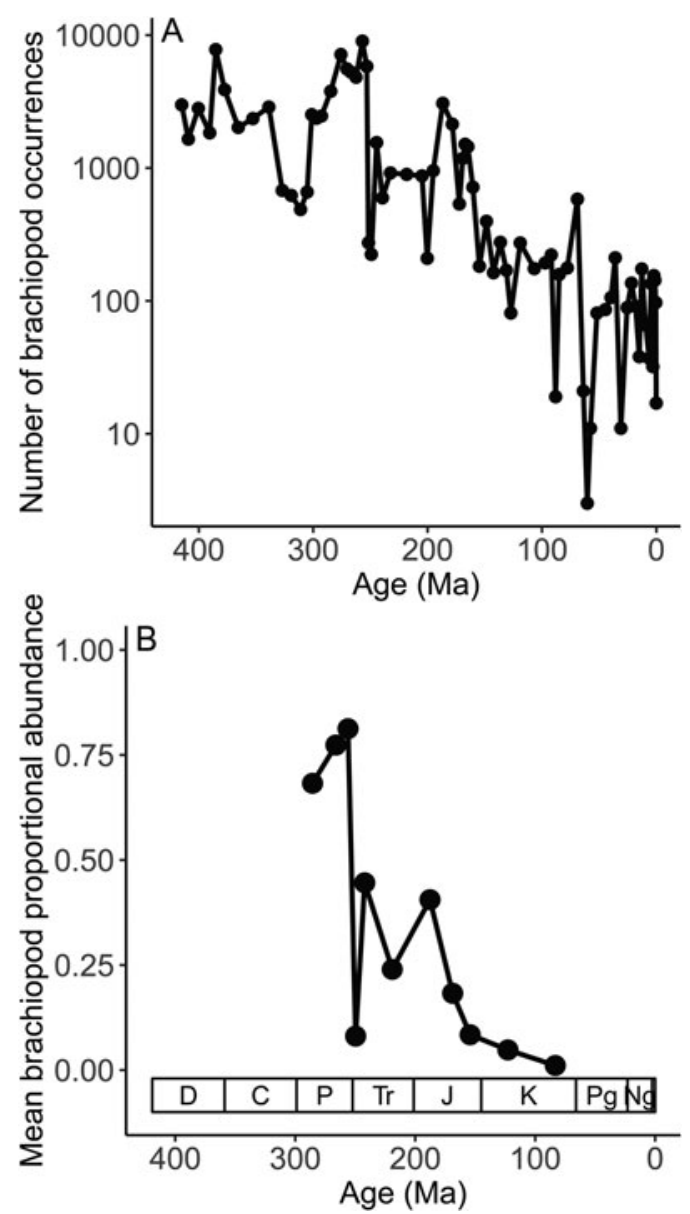

FIGURE 1. Devonian-Quaternary trends in the occurrence and relative abundance of rhynchonelliform brachiopods. A, Number of occurrences in the Paleobiology Database, binned at stage level, showing the gradual mid-Jurassic to early Cenozoic decline. Occurrence scale is log-transformed. B, Mean proportional abundance in bulk-sampled assemblage counts, binned at series level, demonstrating the decline from the Early Jurassic to the Early Cretaceous. The proportion in each assemblage is calculated as the number of rhynchonelliform brachiopod specimens divided by the total number of brachiopod, bivalve, and gastropod specimens. Abbreviations: D, Devonian; C, Carboniferous; P, Permian; Tr, Triassic; J, Jurassic; K, Cretaceous; Pg, Paleogene; $\mathrm{Ng}$, Neogene.

prey (Tyler et al. 2013). Competition for space, at least on hard substrates, is also a possibility, as mussels directly dislodge brachiopods in cage experiments (Thayer 1985) and brachiopods appear more vulnerable to disturbance by grazers or other motile organisms (Tomašových 2008). Finally, increasing bioturbation by deposit-feeding and other infauna during the Jurassic and Cretaceous (Thayer 1979, 1983;
Sepkoski et al. 1991), may also have contributed to the brachiopod decline.

Although some extant brachiopods can occupy soft and even muddy sediments, in some cases attached to small shell fragments or rocks (Richardson and Watson 1975; Richardson 1981b; Stewart 1981; Richardson et al. 2007), most living shallow-marine populations inhabit hard substrates, carbonate sediments, and areas of low to moderate sedimentation (Foster 1974; Noble et al. 1976; Witman and Cooper 1983; Lee 1991; Kowalewski et al. 2002). Brachiopods preferentially occur in such environments because hard and often cryptic attachment sites minimize the burrowing, grazing, and dislodging activity of other organisms (Witman and Cooper 1983; Tomašových 2008). The history of brachiopod substrate dependence extends back to the Mesozoic (Ager 1965; Surlyk 1972; Owen 1978; Alméras and Moulan 1983), suggesting that the mid-Mesozoic decline of brachiopods may have been partially driven by enhanced bioturbation that further disrupted firm substrates (Thayer 1983; Sepkoski et al. 1991). Among other invertebrates, infaunal groups with deeper burrowing habits and/or more intense sediment reworking modes diversified in the Mesozoic, consistent with greater substrate disruption (Thayer 1983). Likewise, thin storm-deposited shell beds were preserved less frequently beginning in the Jurassic and Cretaceous, implying intensification of the bioturbated mixed layer (Brandt 1986; Sepkoski et al. 1991). As a result, Upper Cretaceous strata often were intensely bioturbated, with complex tiering structure similar to modern sediments (Ekdale and Bromley 1991) and evidence for extremely soft to soupy substrates (Bottjer 1981). Ultimately, increased sediment mixing may have created softer substrates that were uninhabitable for many immobile brachiopods (Thayer 1979).

To test the hypothesis that substrate changes contributed to the mid-Mesozoic decline of brachiopods, we quantified the shifting substrate affinities of articulate brachiopods from a global database of fossil occurrences. We also assessed morphological changes in terebratulide and rhynchonellide brachiopods, focusing on characteristics of the beak and pedicle opening that potentially relate to substrate attachment. 
Although the mid-Mesozoic decline of articulate brachiopods likely had multiple causes, our approach will help constrain the role of substrate disruption in the final transition to modern-style benthic communities.

\section{Methods}

We first assessed substrate preferences using global occurrence data of Devonian-Pleistocene brachiopods and bivalves from the Paleobiology Database. We used occurrences identified at any taxonomic level and retained uncertain genus and species identifications, but excluded any occurrence that could not be resolved to stage level. The resulting dataset included 108,678 brachiopod occurrences and 77,260 bivalve occurrences. We classified the lithology of each occurrence as either carbonate or clastic using the primary lithology field; secondary lithologies and lithology adjectives (calcareous, argillaceous, etc.) were ignored. Mixed lithologies (marl, "mixed carbonate-siliciclastic") were also excluded.

Although we did not use specific lithologies or lithology adjectives in the main analysis, some provide additional information about substrate consistency. For examples, shales (including mudstones and claystones) are more likely to represent particularly soft substrates relative to other siliciclastics, whereas glauconitic siliciclastics often reflect sediment starvation and firmer substrates (Van Houten and Purucker 1985). Coarser-grained carbonates (packstones and grainstones) or reef habitats would likely be firmer and would provide more opportunities for brachiopod attachment relative to lime mudstones or wackestones. Similarly, ferruginous carbonates can also form during times of slow sedimentation and may be associated with hardgrounds (Van Houten and Purucker 1985), both suggesting firmer substrates on average. We quantified the proportion of both brachiopods and bivalves that were in shale (relative to other siliciclastics), level-bottom packstones and grainstones (relative to carbonate lithologies of lime mudstone, wackestone, packstone, grainstone, marl, and chalk), reefal carbonates (excluding the perireef or subreef lithology, measured relative to all carbonates), glauconitic siliciclastics (relative to other siliciclastics), and ferruginous carbonates (relative to other carbonates). Because lithologic adjectives such as glauconitic or ferruginous are rare, we grouped occurrences by series (Early Jurassic, Middle Jurassic, etc.).

Substrate preferences derived from global occurrence data can be confounded by geographic shifts in the focus of sampling when well-sampled regions are dominated by a single lithology. For an alternative measure of substrate preferences, we also examined brachiopod relative abundance in collections that report bulk sample counts. To do so, we downloaded Permian-Cretaceous occurrences of brachiopods, bivalves, and gastropods that had abundance counts. The download was filtered to select collections that could be resolved to a single stage; contained at least 25 specimens of brachiopods, bivalves, and/or gastropods; and included counts of the entire shelly fauna rather than of a single group. We checked all collections with 25 or more specimens to determine whether they were bulk-assemblage paleoecological samples, marking unsuitable collections as lacking major groups of macrofossils (collection coverage as "some macrofossils").

The morphology of the brachiopod beak and pedicle foramen also reflects the organism's interaction with its substrate (Richardson 1979, 1981a). Individuals with an incurved beak are more likely to be free-lying, whereas those with a straight or suberect beak are more likely to use the pedicle for attachment to a hard substrate. There are exceptions to that broad trend (e.g., the extant species Neothyris compressa; Chapman and Richardson 1981), but a small to minute pedicle foramen and/or thickened posterior shell region may also imply a free-lying habit (Richardson and Watson 1975; Chapman and Richardson 1981). Some species with an open pedicle foramen may live either free-lying or attached, and may shift to a free-lying habit after outgrowing the attachment surface (Richardson 1981b), but close attachment to a hard substrate may be indicated by an abraded, eroded, or truncated beak (e.g., Hiller et al. 2007). To characterize these morphological traits, we measured foramen width, beak height, beak angle (umbo curvature), shell width, and shell height (Fig. 2) from published illustrations of 217 Jurassic to Quaternary terebratulide species and 


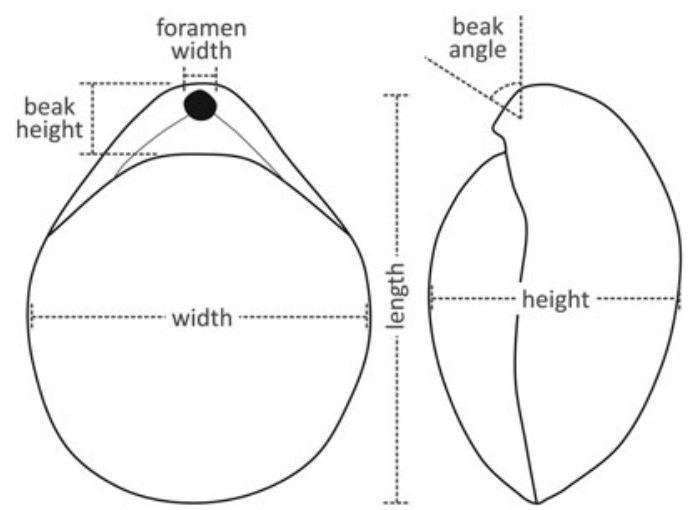

FIGURE 2. Schematic illustration of a terebratulide shell, indicating the measured dimensions (length, width, and height) and parameters. Beak height is the distance from the posterior end of the dorsal valve to the top of the beak. Foramen width is the maximum width of the pedicle foramen. Beak angle is the angle between the commissural plane in lateral view and the orientation of the beak and pedicle foramen.

172 rhynchonellide species, with all linear measurements normalized to shell length. We focused on the Jurassic-Quaternary, because that interval spans the gradual mid- to late Mesozoic decline of articulated brachiopods. We only included species that had a maximum dimension of at least $1 \mathrm{~cm}$, eliminating micromorphic brachiopods that often had highly distinctive morphologies. Although species have intraspecific shape variability, we used one set of foramen and beak measurements per species, basing them on the holotype, if possible, or on a typical individual. Shell width/length and height/length were calculated as the mean of measurements in the Paleobiology Database. We then used principal component analysis (PCA), based on the correlation matrix because of different measurement units for the linear dimensions and beak angle, to create a morphospace of shell shapes. Finally, we recorded from published descriptions whether the species had posterior shell thickening suggestive of a free-lying habit, an eroded or abraded beak suggestive of an attached habit, or a labiate foramen suggestive of a functioning pedicle.

\section{Results}

Brachiopod Abundance.-Rhynchonelliform brachiopods have preferentially occurred in

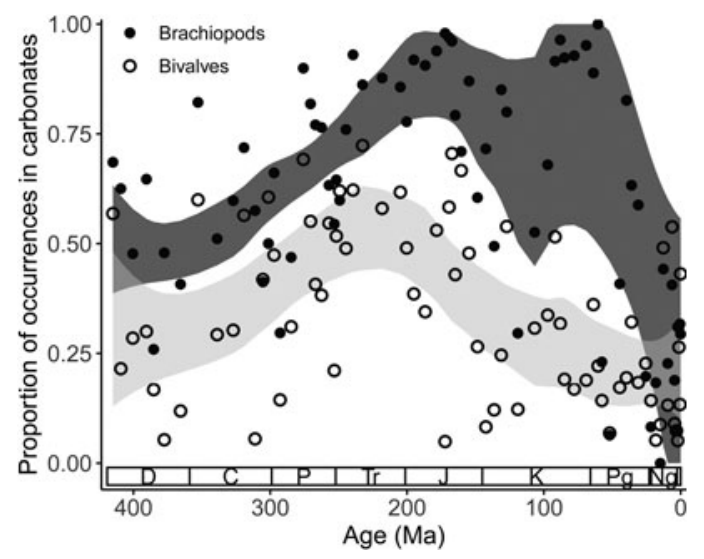

FIGURE 3. Proportion of rhynchonelliform brachiopod (solid circles) and pteriomorph bivalve (open circles) occurrences in carbonate lithologies, binned by stage. Shaded fields show $95 \%$ confidence intervals on LOESS local regressions (smoothing parameter of 0.5 and weighting observations by the number of occurrences) for brachiopod (dark gray) and bivalve (light gray) trends, shown only to smooth sampling-related volatility. Brachiopods typically occurred in carbonates more frequently than bivalves, but the substrate difference was wider in the Mesozoic and Paleogene. Abbreviations: D, Devonian; C, Carboniferous; P, Permian; Tr, Triassic; J, Jurassic; K, Cretaceous; Pg, Paleogene; $\mathrm{Ng}$, Neogene.

carbonate lithologies since at least the Devonian, but were especially prevalent in carbonates during the Jurassic and Cretaceous (Fig. 3). The typical proportion of global occurrences in carbonates increased from about $50 \%$ in the Devonian and Carboniferous to around $90 \%$ in the Jurassic and Cretaceous, but decreased sharply to $25 \%$ (although with a broad 95\% confidence interval from $0 \%$ to $60 \%$ ) by the Neogene and Quaternary. These trends are partially controlled by the exposed lithologies in well-sampled regions (particularly North America and Europe), which were predominantly carbonates in the Triassic and Jurassic but predominantly siliciclastics in the Neogene. Nevertheless, the increased preference of brachiopods for carbonate substrates is likely a real phenomenon, in excess of shifts in the availability of carbonate lithologies in wellsampled regions. Epifaunal pteriomorph bivalves typically occurred less frequently in carbonates than brachiopods, especially from the Triassic to the Paleogene (Fig. 3), implying that brachiopods had a stronger carbonate preference than other epifaunal taxa. In addition, 


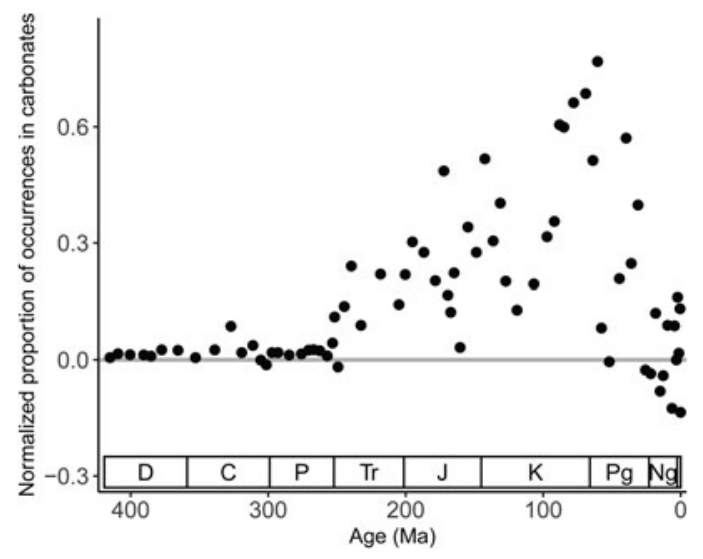

FIGURE 4. Proportion of rhynchonelliform brachiopod occurrences in carbonate lithologies, normalized by subtracting the proportion of all marine invertebrate occurrences in carbonate lithologies. During the late Paleozoic, rhynchonelliform brachiopods occurred in carbonates about as frequently as marine invertebrates as a whole, but brachiopods tended to occur in carbonates much more frequently from the Triassic to the Paleogene. Abbreviations: D, Devonian; C, Carboniferous; P, Permian; Tr, Triassic; J, Jurassic; K, Cretaceous; Pg, Paleogene; $\mathrm{Ng}$, Neogene.

the normalized proportion of rhynchonelliform brachiopod occurrences in carbonates (after subtracting the proportion of all marine invertebrate occurrences in carbonates) indicates greater preference for carbonates during the Jurassic and Cretaceous (Fig. 4). The proportion of brachiopod occurrences in carbonates was not elevated relative to the overall proportion of carbonate occurrences during the DevonianPermian or during the Neogene and Quaternary.

Abundance data from individual collections avoid many of the complexities of occurrence data and confirm the preferential occurrence of Mesozoic brachiopod on carbonate substrates. Rhynchonelliform brachiopods were abundant in both carbonates and siliciclastics during the Permian, even more abundant in siliciclastics during the Cisuralian and Lopingian (Fig. 5). Brachiopods were extremely rare during the Early Triassic, but were considerably more abundant in carbonate samples during much of the Triassic and Jurassic, except for the Late Jurassic and perhaps Middle Triassic. By the Late Cretaceous, brachiopods were rare in both carbonate and siliciclastic collections that had abundance data. Overall, the early Mesozoic resurgence of rhynchonelliform brachiopods was driven almost entirely by carbonate habitats; brachiopods remained rare in collections from siliciclastics, except during the Middle Triassic.

Evidence from specific lithologies is more equivocal, however. Among siliciclastic occurrences, brachiopods were not consistently underrepresented in shales (including mudstones and claystones) during the Mesozoic (Fig. 6), even though those lithologies are more likely to represent soft substrates compared to coarser siliciclastics. The proportion of brachiopod occurrences in shales was lower than the proportion of epifaunal bivalves during the Late Triassic, Late Jurassic, and possibly the Late Cretaceous, but higher in the Early Jurassic and Early Cretaceous, and possibly the Middle Triassic and Middle Jurassic. However, brachiopods consistently occurred at lower frequencies in shales during the Paleogene, Neogene, and Quaternary, as compared with bivalves.

In level-bottom carbonate habitats, brachiopods tended to be overrepresented in coarsergrained packstone and grainstone carbonate sediments in the Late Jurassic, Paleogene, Neogene, and Quaternary, and therefore underrepresented in finer-grained wackestone, lime mudstone, marl, and chalk (Fig. 7A). The proportion of brachiopod occurrences in coarsergrained carbonates was similar to that of bivalves during most other time intervals, although brachiopods were underrepresented during the Middle Triassic. There was less difference in frequency in reef habitats relative to all carbonate occurrences; brachiopods and bivalves had occurred at similar frequencies in most time intervals (Fig. 7B). The most notable trend is an increasingly strong underrepresentation of brachiopods during the Neogene and Quaternary, largely driven by a substantial proportion of bivalve carbonate occurrences deriving from reef collections.

Glauconite-bearing siliciclastics are more likely to represent firm substrates during sediment starvation, but brachiopods were only overrepresented relative to bivalves during the Late Jurassic and the Late Cretaceous, and underrepresented in the Paleogene (Fig. 8). Brachiopods and epifaunal bivalves had similar prevalence in glauconitic siliciclastics during 


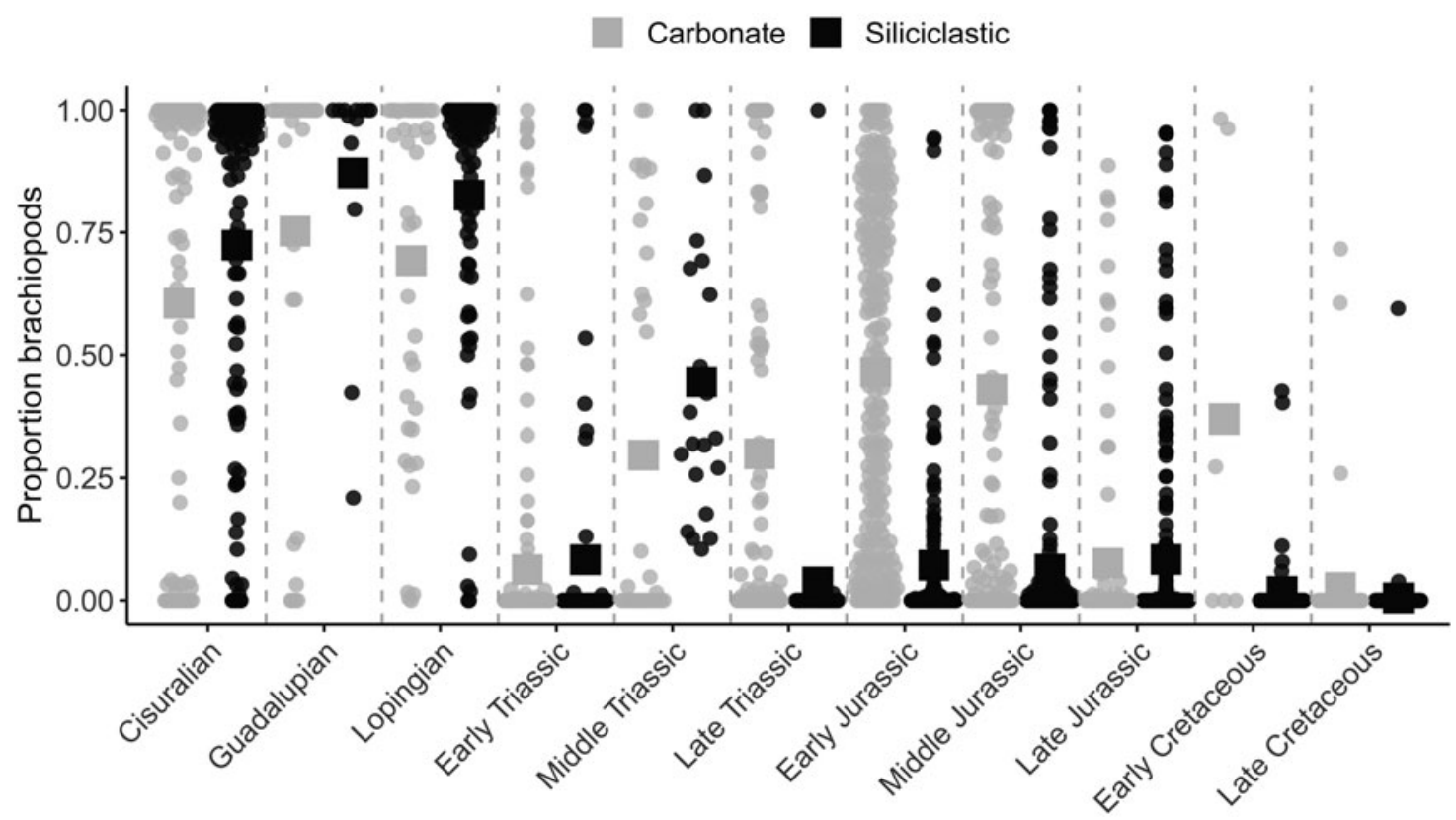

FIGURE 5. Proportional abundance of rhynchonelliform brachiopods in Permian-Cretaceous bulk-sampled assemblages, binned at series level. Circles show proportions for individual assemblages (carbonate in gray; siliciclastic in black), with large square symbols indicating the mean proportion by lithology. Rhynchonelliform brachiopods were very rare in siliciclastic assemblages beginning in the Late Triassic, but remained moderately abundant in carbonate assemblages until the Middle Jurassic.

the Early Cretaceous, and glauconite was an extremely rare adjective in Paleobiology Database collections from the Late Triassic through

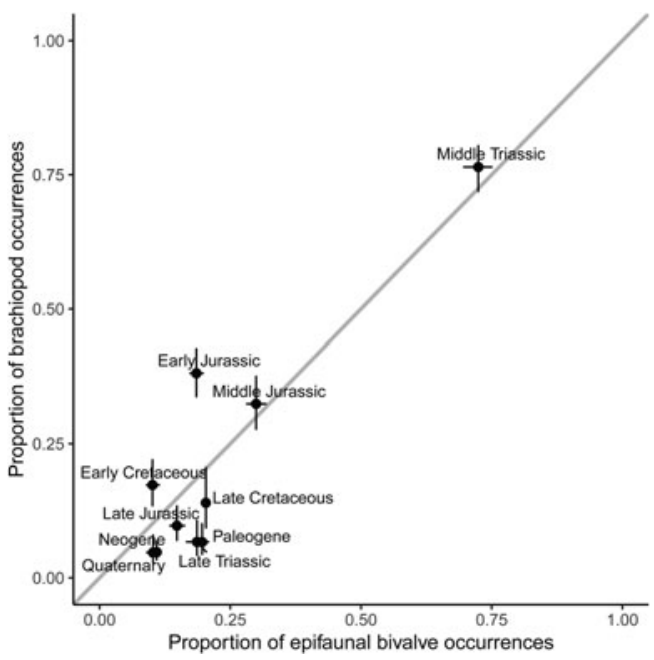

FIGURE 6. Proportional occurrence of rhynchonelliform brachiopods and epifaunal (pteriomorph) bivalves in shale, mudstone, or claystone lithology relative to all siliciclastic occurrences, binned by Middle Triassic-Quaternary series/periods. The gray line shows a 1:1 trend.
Middle Jurassic and in the Neogene and Quaternary. Finally, ferruginous carbonates may also be more likely to represent sediment starvation and hardground development, and brachiopods may have been overrepresented relative to epifaunal bivalves in those environments. Although ferruginous carbonates are rare in Paleobiology Database collections, brachiopods were overrepresented in the Late Cretaceous and Early Jurassic, and especially during the Middle Jurassic and Early Cretaceous (Fig. 8). However, during the Late Jurassic and Paleogene, brachiopods were instead underrepresented in ferruginous carbonates relative to epifaunal bivalves.

Terebratulide Morphology. - Larger terebratulide species $(>10 \mathrm{~mm})$ with abraded beaks occur at positive PC 1 values on the morphospace (Fig. 9). PCA loadings indicate that these species are characterized by a small umbo curvature (beak angle), indicating a suberect or even straight beak, and that they also tend to have larger foramen widths. In contrast, terebratulides with posterior shell thickening tend to occur at negative values of PC 1, but 


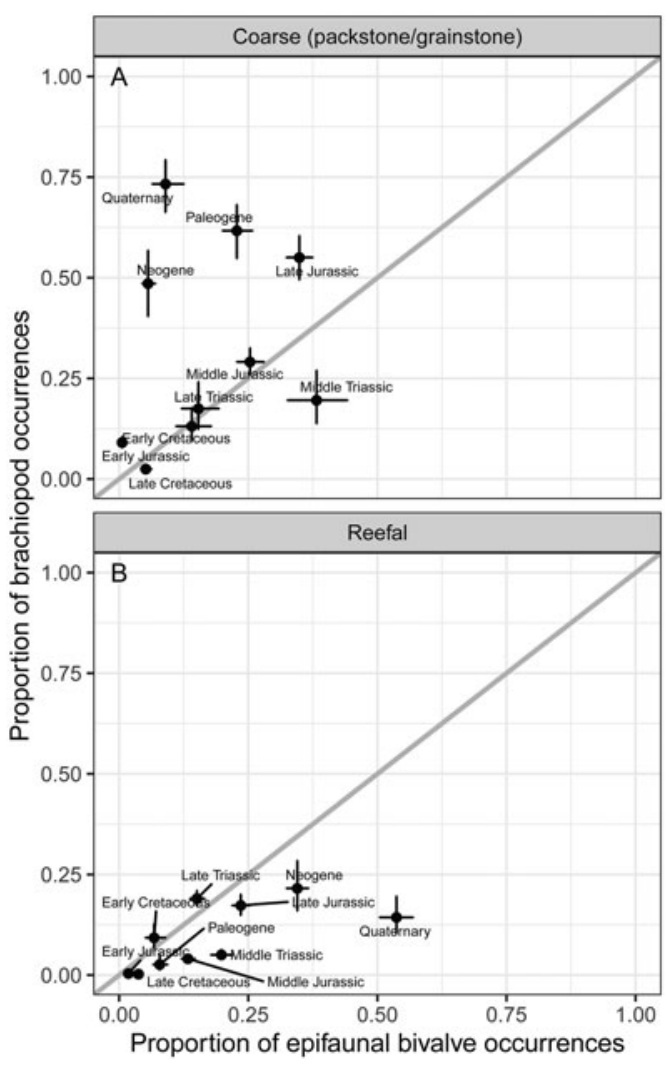

FIGURE 7. Proportion of brachiopod and epifaunal (pteriomorph) bivalve carbonate occurrences that are in (A) coarser lithologies (packstone and grainstone), and (B) reef environments. The gray lines show 1:1 trends.

overlap with abraded species at intermediate PC 1 and high PC 2 values. Species with larger umbo curvature are likely to also have posterior thickening, but thickening can nevertheless occur in species with suberect to straight beaks. PCA loadings indicate that species with posterior thickening also tend to have moderate to small foramen widths and low beak heights. Finally, species with a labiate foramen typically occupy an intermediate region of the morphospace, overlapping with the other two groups at higher PC 2 values but positioned between abraded and posteriorly thickened species at low PC 2 values. Overall, the PCA results highlight a shift from abraded, through labiate, to posteriorly thickened species along the PC 1 axis. The trend is present, although with greater overlap among all three groups, in species with smaller height/length ratio (lower shell convexity or a more

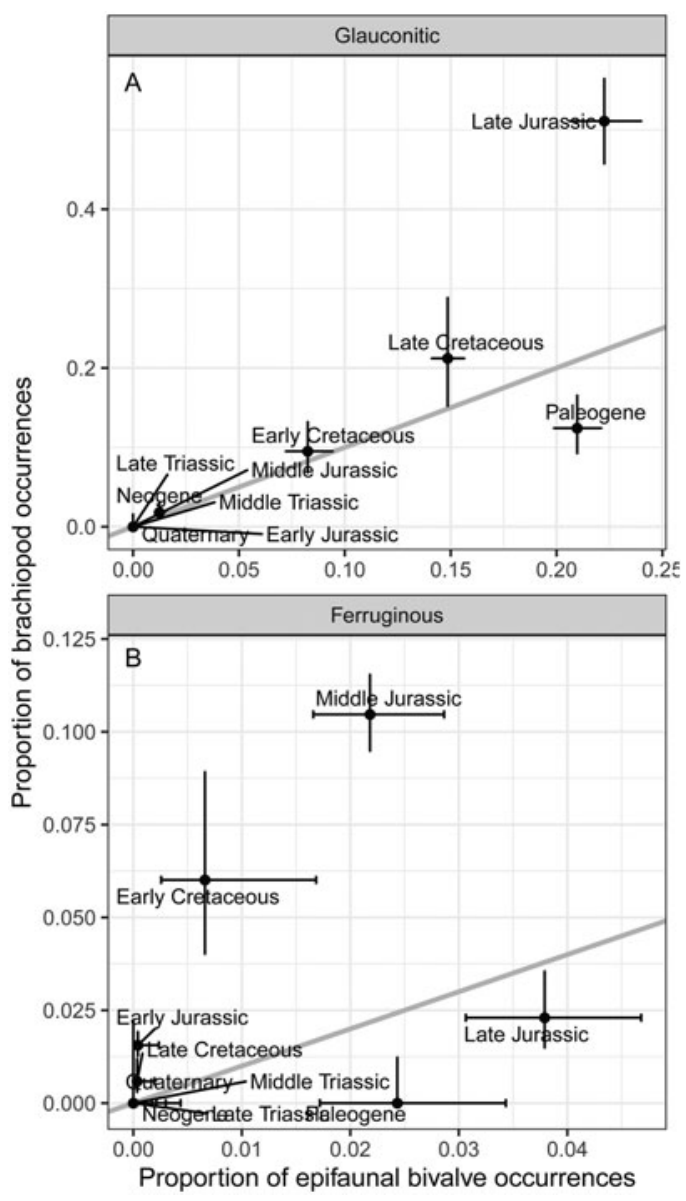

FIGURE 8. Proportion of brachiopod and epifaunal (pteriomorph) bivalve siliciclastic occurrences that are from glauconitic clastics (A) and proportion of carbonate occurrences that are from ferruginous carbonates (B). The gray lines show 1:1 trends.

compressed shape, at higher PC 2 values). However, separation between the three groups is clearest at negative PC 2 values in species with a greater height/length ratio (greater shell convexity or a more inflated shape).

During the Early and Middle Jurassic, terebratulides typically occupied a narrow range in the central part of PC 1, but a broad range across PC 2 (Fig. 10). A few species exhibited posterior shell thickening, while only one in the dataset had an abraded beak. In contrast, species with a labiate foramen were common, particularly in the Middle and Late Jurassic. The centroid in each interval was located at negative PC 1 and PC 2 values. Between the Late Jurassic and Paleogene, the terebratulide 


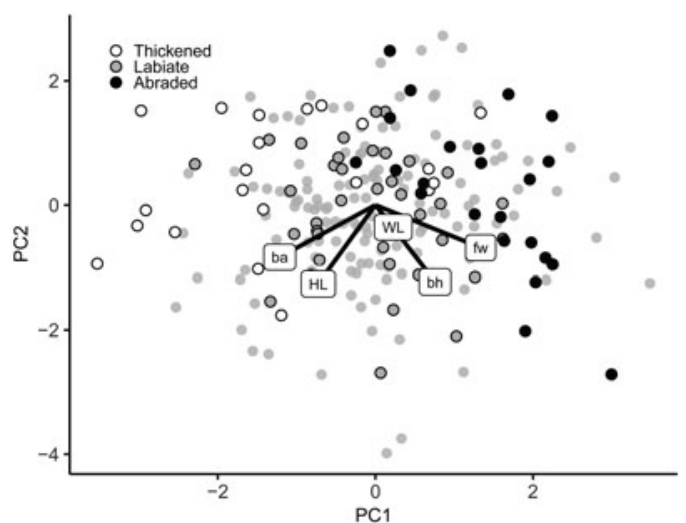

FIGURE 9. Principal component analysis (PCA) of JurassicQuaternary terebratulide shell morphology, based on beak angle (ba), foramen width (fw), beak height (bh), and shell width/length (WL) and height/length (HL, or convexity) ratios. Open symbols indicate species with posterior shell thickening; gray symbols indicate species with a labiate pedicle foramen; and solid black points indicate species with an abraded or eroded pedicle. Gray points without a border show species that lack any of those three characteristics.

centroid shifted to higher PC 1 and PC 2 values, indicating a transition to smaller height/length values (lower convexity), and straighter beaks. Overall, beak height and pedicle foramen width did not change substantially. However, species with higher beaks and larger foramen widths tended to have a more incurved umbo in the Jurassic, but had a straighter umbo in the Cenozoic. Shell width/length varied along PC 3, but there were no temporal trends in that trait. Although the centroid shifted on average to higher PC 1 values, terebratulides expanded their morphology both to higher PC 1 values (including species with abraded beaks) and to lower PC 1 values (more species with posterior shell thickening). Although micromorphic brachiopods with a large pedicle foramen and abraded beak were already common in the Cretaceous, larger species with abraded beaks became particularly common beginning in the Paleogene.

Rhynchonellide Morphology.-Few rhynchonellide species in the dataset are described as possessing shell thickening (four species) or a labiate foramen (one species), and none had an abraded beak. Given the small sample size, it is difficult to determine whether rhynchonellides and terebratulides had a similar relationship between shell morphology and

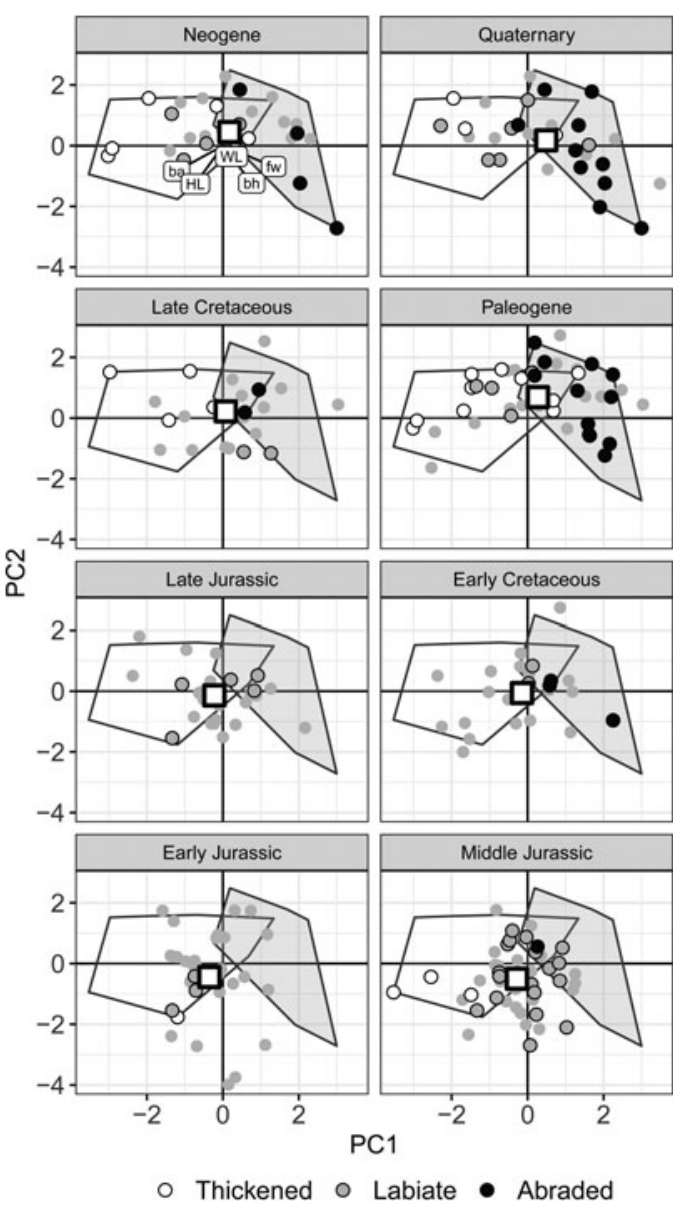

FIGURE 10. Principal component analysis (PCA) of JurassicQuaternary terebratulide shell morphology, based on beak angle (ba), foramen width (fw), beak height (bh), and shell width/length (WL) and height/length (HL, or convexity) ratios, and grouped by Mesozoic series and Cenozoic period. Open symbols indicate species with posterior shell thickening; gray symbols indicate species with a labiate pedicle foramen; and solid black points indicate species with an abraded or eroded beak. Gray points without a border show species that lack any of those three characteristics. The white polygon indicates the morphospace range occupied by species with posterior shell thickening; the gray polygon indicates the morphospace range occupied by species bearing an abraded beak. Larger squares are the centroids for each time period.

those traits. However, three of the species with shell thickening had small foramen widths and beak heights, and all four had greater than average umbo curvature (Figs. 11, 12).

During the Early Jurassic through Late Cretaceous, many rhynchonellide species occupied the lower left quadrant of the PC 1 versus PC 2 morphospace, indicating more globose shells with higher width/length and height/length 


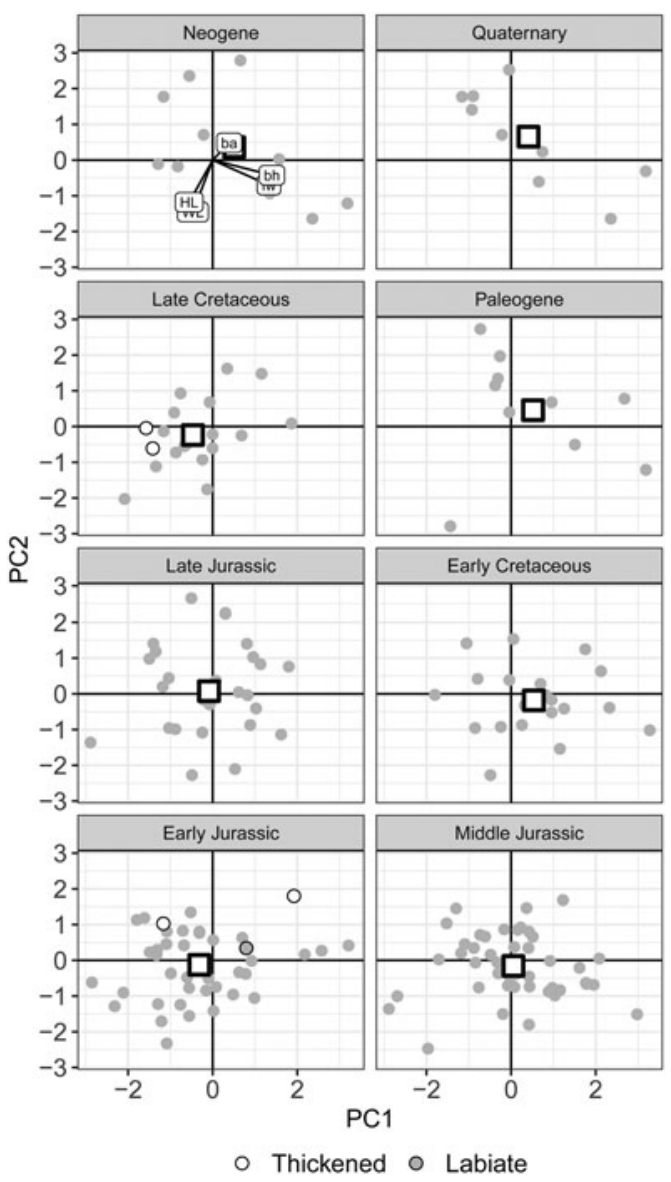

FIGURE 11. Principal component analysis (PCA) of Jurassic-Quaternary rhynchonellide shell morphology (PC 1 vs. PC 2), based on beak angle (ba), foramen width (fw), beak height (bh), and shell width/length (WL) and height/length (HL, or convexity) ratios, and grouped by Mesozoic series and Cenozoic period. Open symbols indicate species with posterior shell thickening; gray symbols indicate species with a labiate pedicle foramen (no species had an abraded or eroded beak). Gray points without a border show species that lack any of those three characteristics. Larger squares are the centroids for each time period.

ratios and smaller beak heights and foramen widths (Fig. 11). In contrast, that region of the morphospace was nearly empty in the Paleogene, Neogene, and Quaternary, similar to the shift to species with narrower and less-inflated shells among terebratulides. Rhynchonellides also exhibited a shift toward straighter beaks on PC 3 (Fig. 12), driven primarily by a decrease in forms with larger beak curvature. However, rhynchonellides only moved slightly toward having a longer beak or a larger pedicle foramen, shown best by a shift toward more

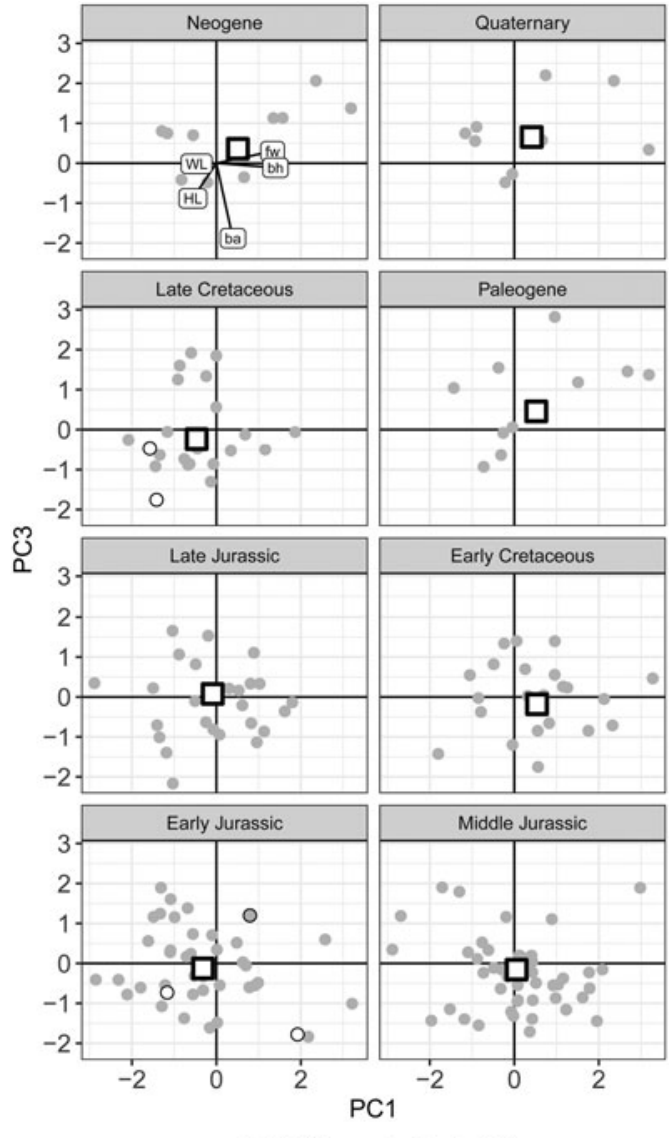

○ Thickened $\bigcirc$ Labiate

FIGURE 12. Principal component analysis (PCA) of Jurassic-Quaternary rhynchonellide shell morphology (PC 1 vs. PC 3), based on beak angle (ba), foramen width (fw), beak height (bh), and shell width/length (WL) and height/length (HL, or convexity) ratios, and grouped by Mesozoic series and Cenozoic period. Open symbols indicate species with posterior shell thickening; gray symbols indicate species with a labiate pedicle foramen (no species had an abraded or eroded beak). Gray points without a border show species that lack any of those three characteristics. Larger squares are the centroids for each time period.

positive PC 1 values (Figs. 11, 12). Although the average shift was small, species with a large foramen width and tall beak tended to have a more incurved umbo in the Early and Middle Jurassic, but a straighter umbo in the Cenozoic. Despite that, no rhynchonellide species in the database had an abraded beak, in contrast with the abundance of terebratulides with abraded beaks during the Cenozoic. Whereas terebratulides evolved into new areas of the morphospace, especially with the development of forms with a large pedicle 
foramen and abraded beak, Cenozoic rhynchonellides instead occupied a subset of the morphological range found in Jurassic species.

\section{Discussion}

Did Brachiopods Preferentially Shift to Firmer Substrates? - Occurrence and within-collection abundance patterns, both overall and relative to epifaunal bivalves, imply that brachiopods lived preferentially in carbonate lithologies during the Mesozoic, especially the Jurassic and Cretaceous. Global occurrence patterns are more difficult to interpret, but brachiopods were more common constituents of bulksampled carbonate assemblages during much of the Mesozoic (Fig. 5). But did their preference occur because of the firmer consistency of carbonate substrates? Substrate consistency is controlled by many parameters but, compared with siliciclastics, carbonates tend to be more prone to early diagenetic cementation, especially in tropical settings and when sedimentation rates are slow (Purser 1969; Smith and Nelson 2003). Although firmgrounds can develop in winnowed fine-grained siliciclastics, and carbonate sediments can also become soft or soupy, on average carbonates should provide firmer substrates for sessile benthic organisms. Late Triassic and Early Jurassic brachiopods could be abundant even in finegrained carbonates (Fürsich et al. 2001; Tomašových 2006), but later Jurassic and Cretaceous brachiopods were often reported at firmgrounds or hardgrounds (Eyers 1992; Ruffell and Wach 1998) and other firmer substrate types (coarser-grained shallow-water facies, hard reef substrates, or highly glauconitic and condensed sections), and could be rare in finergrained and likely softer offshore facies (Ager 1965; Owen 1978; Alméras and Moulan 1983). Hardgrounds are not consistently reported in the taxonomic literature and therefore are probably underrepresented in the Paleobiology Database, but brachiopods do not exhibit consistent overrepresentation in ferruginous carbonates (Fig. 8), which may often be associated with sediment starvation and possibly firmgrounds and hardgrounds. Likewise, brachiopods are overrepresented in glauconitic siliciclastics, possibly representing sediment starvation and firmer substrates, but only in some intervals (Fig. 8). Brachiopods are also generally not overrepresented in reef collections relative to epifaunal bivalves (Fig. 7), despite reefs providing abundant hard substrates and despite brachiopod genera preferentially originating in reef habitats (Kiessling et al. 2010). This is not the expectation if substrate was a strong influence on brachiopod habitats, although the discrepancy may have been caused more by preferential data entry of reefassociated bivalves in the Neogene and Quaternary, as brachiopods occur frequently in reef collections in an absolute sense during those intervals ( $14 \%$ of carbonate collections in the Quaternary and nearly $22 \%$ in the Neogene). However, the preferential occurrence of brachiopods in coarser-grained packstones and grainstones in the Cenozoic is consistent with a substrate firmness prediction.

Although brachiopods were overrepresented in Mesozoic carbonates, most Neogene and Quaternary brachiopod occurrences in the Paleobiology Database are instead from siliciclastic substrates. Those siliciclastic occurrences partly reflect extensive sampling of predominantly siliciclastic European localities, but there is still little evidence for a carbonate lithologic preference even after normalizing to the overall distribution of lithologies (Fig. 4). Does this imply that substrate had ceased to influence brachiopod habitat by the Neogene, despite high bioturbation intensity that was presumably comparable to the modern? Although brachiopods commonly occurred in siliciclastic collections in the Paleobiology Database during the Cenozoic, those occurrences are nearly exclusively from coarse-grained, often gravel, substrates. The underrepresentation of brachiopods in finer-grained shale, mudstone, and claystone lithologies (Fig. 6) is consistent with the rarity of extant brachiopods in mud-dominated habitats (Tomašových and Kidwell 2017) and suggests that similar substrate constraints operated during the Cenozoic. Many Neogene and Quaternary brachiopod occurrences also come from temperate latitudes, where early diagenetic lithification would have been less prevalent compared with tropical sites (Smith and Nelson 2003), potentially reducing substrate differences between carbonates and siliciclastics. Finally, 
reduced lithologic preference in Paleobiology Database data may also reflect the abundance of micromorphic and other small brachiopods such as Terebratulina, Argyrotheca, Megerlia, Megathiris, and Joania (accounting for 30\% of Neogene-Pleistocene occurrences) that were able to attach to shell fragments, rocks, or other hard substrates, or even to other brachiopods (Thomsen 2005), increasing their ability to live on siliciclastic or other soft substrates.

Although not all substrate indicators fully align with the habitat preference hypothesis, we argue that the preponderance of evidence supports a role for changing substrate in the gradual decline of brachiopods. Inconsistent or equivocal relationships tend to occur in rare lithologic categories (e.g., ferruginous or glauconitic sediments) that have small sample sizes and are less likely to be consistently reported in taxonomic papers. In contrast, patterns from broader lithologic categories that are more widely reported and have larger sample sizes, such as carbonates/siliciclastics and mudstones/shales, largely support the idea that expansion of softer substrates increasingly excluded brachiopods during the late Mesozoic and Cenozoic.

Potential Effects of Predation.-Increased durophagous predation was also a major macroevolutionary and ecological force during the Mesozoic marine revolution (Vermeij 1977, 2008; Monarrez et al. 2017). Other sessile groups, such as stalked crinoids, declined in diversity and shifted to offshore habitatsboth potentially consequences of enhanced predation pressure (Bottjer and Jablonski 1988; Gorzelak et al. 2012). The expansion of infauna in multiple groups, ultimately the cause of increased substrate disruption during the Mesozoic, likely also represents a response to predatory escalation (Vermeij 2008).

Mesozoic brachiopods undoubtedly were affected by enhanced predation, but predation seems like a less plausible explanation for the specific brachiopod occurrence and abundance data documented here. Predatory escalation is thought to have been more pronounced in productive tropical habitats (Vermeij 2008), yet brachiopods remained more abundant in carbonates than in siliciclastics during Mesozoic. Carbonate habitats instead may have served as refugia where brachiopods could persist on firmer substrates at greater abundances during the late Mesozoic. The locally high abundance of Jurassic-Cretaceous brachiopods in Europe also contrasts with their rarity in North America (Ager et al. 1963; Steele-Petrović 1979), even though both regions occupied similar subtropical latitudes more consistent with substrate differences than with predatory escalation. European Jurassic localities often contained thin or condensed sections, favoring firmground or hardground development that provided suitable brachiopod habitat (Purser 1969; Eyers 1992; Ruffell and Wach 1998), whereas higher sedimentation rates in much of the North American Mesozoic might have led to fewer firmgrounds or hardgrounds, thus potentially rarer or more localized brachiopod occurrences.

Did Morphology Respond to Changing Substrate?-Morphology reflects multiple selective factors, along with constructional and evolutionary constraints, but Mesozoic and Cenozoic brachiopods exhibited shifts in traits that relate to substrate attachment. Overall, many Jurassic terebratulides occupied regions of the morphospace distinct from their Cenozoic counterparts (Fig. 10), with a combination of more strongly incurved beaks, larger pedicle foramen openings and beak heights for a given beak curvature, and greater shell convexity. Rhynchonellides underwent a similar but less pronounced shift, also exhibiting more convex shells and greater beak curvature in the Jurassic compared with the Cenozoic (Fig. 11). Among terebratulides, the morphological shift was accompanied by an increase both in the frequency of species with abraded beaks and in the frequency of species with posterior shell thickening, while a greater proportion of Mesozoic species had a labiate pedicle foramen. Together, these trends are consistent with increasing specialization for substrate attachment, both closer attachment to hard substrates (straighter and abraded beaks with larger foramen widths) and adaptations for free-lying habits (posterior shell thickening and, in some cases, an incurved umbo with tiny pedicle foramen).

However, rhynchonellides underwent less pronounced morphological shifts compared 


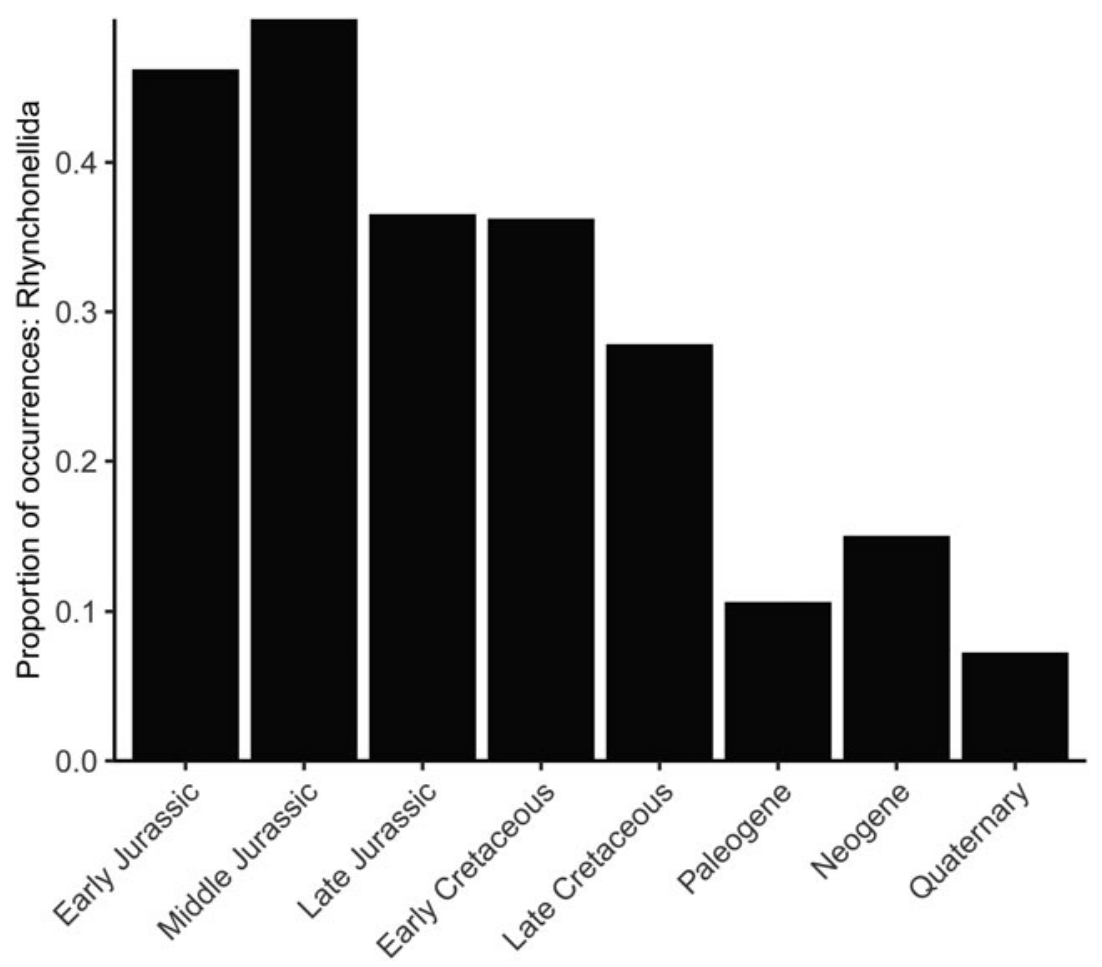

FIGURE 13. Proportion of all brachiopod occurrences that belong to the order Rhynchonellida, grouped by series in the Jurassic and Cretaceous and by period in the Cenozoic.

with terebratulides, despite exhibiting similar types of shape change. Rhynchonellides also tended toward lower shell convexity and straighter beaks, but none of the Cenozoic species in the dataset had abraded beaks, even though some (e.g., Notosaria nigricans) attach to rock substrates (Lee 1978). The weaker response of rhynchonellides could cast doubt on the generality of substrate change as a macroecological and macroevolutionary driver. However, rhynchonellides also decreased from more than $40 \%$ of brachiopod occurrences in the Early and Middle Jurassic to only $10 \%$ of Cenozoic occurrences (Fig. 13). This disproportionate decline is consistent with the importance of substrate, where more pronounced morphological shifts among terebratulides made that group less susceptible to substrate disruption, while rhynchonellides failed to respond to the same degree and declined in importance.

Many Jurassic brachiopods had morphologies that are rare or absent among Cenozoic and extant species, most notably highly biconvex forms with long, incurved beaks and larger pedicle foramen widths. If substrate attachments played a role in the functional morphology, what life habit does that suggest for these non-analogue forms? Their morphology differs from extant free-lying Neothyris or Anakinetica, suggesting a different attachment strategy. Many extant brachiopods inhabit unconsolidated substrates, but attach via pedicle to shell fragments, small rocks, or other hard surfaces (Richardson 1981b) or sometimes to tiny grains when the pedicle divides into small rootlets (Rudwick 1961). However, these species tend to be more convex and have straighter and shorter beaks than Jurassic non-analogue forms. Extant species can also live attached to larger rock outcrops (Richardson 1981b) — even the characteristically freelying Neothyris can occasionally be found attached to rock walls (Chapman and Richardson 1981). In the extant Magasella sanguinea, populations on unconsolidated substrates have greater shell convexity (Richardson et al. 2007). Given that, the greater convexity typical 
of many Jurassic forms could be consistent with a primary life habit on firm-substrate habitats, rather than the flexible strategy of modern brachiopods that often attach to hard substrates. These morphologies may have maintained pedicle attachment throughout some of their ontogeny, as suggested by the more frequent occurrence of large foramen sizes and labiate pedicles, but many may have shifted to an unattached life habit resting on and supported by the more stable substrate (e.g., Manceñido and Walley 1979; Feldman et al. 2015) An inflated shape may have helped to elevate the commissure above the seafloor even if the shell was primarily supported by resting on the sediment, analogous to the reclining lifestyle of similarly shaped gryphaeid bivalves (LaBarbera 1981) and other iceberg strategists (Thayer 1975). Like the gryphaeids, these nonanalogue brachiopod morphologies may have disappeared largely as a consequence of enhanced bioturbation that disrupted the substrates and restricted the surviving taxa to certain habitats and specialized adaptations.

\section{Conclusions}

Overall, the occurrence and morphological trends imply that bioturbation-driven substrate changes could have been a major contributor to the Mesozoic-Cenozoic decline of brachiopods. After living in nearly all habitats in the Paleozoic, Mesozoic brachiopods initially became excluded from siliciclastic environments, especially those with fine grain size, and disproportionately occurred in carbonate lithologies that may have provided firmer substrates. There are no clear substrate preferences in rare lithologies, such as glauconitic or ferruginous substrates or reef habitats, but among more widely reported lithologies, brachiopods became more common in coarse-grained carbonates and rare in fine-grained siliciclastics. By the Neogene, brachiopods typically occurred in gravelly siliciclastics, coarse carbonates, and reef habitats, similar to their extant distribution. This represents a significant reduction in habitat availability, which would have contributed to the gradual decrease in both diversity and abundance since the Early Jurassic.
At the same time as bioturbation likely restricted habitat availability for brachiopods, many species, especially among terebratulides, underwent morphological shifts consistent with changing attachment strategies. Highly convex forms in the Jurassic may have partially rested on firmer seafloors, but declined and were replaced by Cenozoic species with abraded or eroded beaks implying attachment to hard substrates. Rhynchonellides exhibited similar but much less pronounced morphological shifts, and as a result declined disproportionately in abundance and diversity relative to the more successful terebratulides. Although a few brachiopods became adapted for a free-living lifestyle and others shifted to live on hard substrates, the limited availability of such substrates contributed to the decline of brachiopods since the Jurassic.

The decline in brachiopod diversity and abundance, their near-restriction to hard substrates, and significant shifts in shell morphology were major macroevolutionary consequences of Meso-Cenozoic escalation in marine ecosystems. Escalation of predatory intensity likely was a contributor, but the occurrence and morphological data also imply a role for substrate changes caused by intensification of bioturbation and biological bulldozing. While the initial step in the demise of brachiopods was an abrupt shock from the end-Permian mass extinction, their final decline was instead a gradual process driven by biological interactions as increasingly active bioturbators transformed the seafloors into soft sediments that are largely inhospitable to sessile epifauna such as brachiopods.

\section{Acknowledgments}

We thank A. Tomašových, an anonymous reviewer, and Paleobiology editor W. Kiessling for valuable feedback. Partial funding was provided by the American Chemical Society Petroleum Research Fund, award 54675-ND8. This is Paleobiology Database publication no. 384.

\section{Literature Cited}

Ager, D. V. 1965. The adaptation of Mesozoic brachiopods to different environments. Palaeogeography, Palaeoclimatology, Palaeoecology 1:143-172. 
Ager, D. V., J. R. Underwood, and R. K. Deford. 1963. New Cretaceous brachiopod from Trans-Pecos Texas. Journal of Paleontology 37:371-378.

Alméras, Y., and G. Moulan. 1983. Influence des paléoenvironnements sur la phylogéniedes brachiopodes. Exemple des Térébratulidés du Lias provencal (France). Geobios 16:243-248.

Bottjer, D. J. 1981. Structure of Upper Cretaceous chalk benthic communities, southwestern Arkansas. Palaeogeography, Palaeoclimatology, Palaeoecology 34:225-256.

Bottjer, D. J., and D. Jablonski. 1988. Paleoenvironmental patterns in the evolution of post-Paleozoic benthic marine invertebrates. Palaios 3:540-560.

Brandt, D. S. 1986. Preservation of event beds through time. Palaios 1:92-96.

Bush, A. M., R. K. Bambach, and G. M. Daley. 2007. Changes in theoretical ecospace utilization in marine fossil assemblages between the mid-Paleozoic and late Cenozoic. Paleobiology 33:76-97.

Chapman, B. E., and J. R. Richardson. 1981. Recent species of Neothyris (Brachiopoda. Terebratellinae). New Zealand Journal of Zoology 8:157-161.

Clapham, M. E., and D. J. Bottjer. 2007. Prolonged Permian Triassic ecological crisis recorded by molluscan dominance in Late Permian offshore assemblages. Proceedings of the National Academy of Sciences USA 104:12971-12975.

Donovan, S. K., and A. S. Gale. 1990. Predatory asteroids and the decline of the articulate brachiopods. Lethaia 23:77-86.

Ekdale, A. A., and R. G. Bromley. 1991. Analysis of composite ichnofabrics: an example in uppermost Cretaceous chalk of Denmark. Palaios 6:232-249.

Eyers, J. 1992. Sedimentology and palaeoenvironment of the Shenley Limestone (Albian, Lower Cretaceous): an unusual shallow-water carbonate. Proceedings of the Geologists' Association 103:293-302.

Feldman, H. R., M. Schemm-Gregory, M. A. Wilson, and F. Ahmad. 2015. Talexirhynchia, a new rhynchonellid genus from the Jurassic Ethiopian Province of Jordan. Paläontologische Zeitschrift 89:25-35.

Finnegan, S., C. M. McClain, M. A. Kosnik, and J. L. Payne. 2011. Escargots through time: an energetic comparison of marine gastropod assemblages before and after the Mesozoic Marine Revolution. Paleobiology 37:252-269.

Foster, M. W. 1974. Recent Antarctic and subantarctic brachiopods. Antarctic Research Series 21:1-189.

Fraiser, M. L., and D. J. Bottjer. 2007. When bivalves took over the world. Paleobiology 33:397-413.

Fürsich, F. T., R. Berndt, T. Scheuer, and M. Gahr. 2001. Comparative ecological analysis of Toarcian (Lower Jurassic) benthic faunas from southern France and east-central Spain. Lethaia 34:169-199.

Gorzelak, P., M. A. Salamon, and T. K. Baumiller. 2012. Predatorinduced macroevolutionary trends in Mesozoic crinoids. Proceedings of the National Academy of Sciences USA 109:7004-7007.

Gould, S. J., and C. B. Calloway. 1980. Clams and brachiopodsships that pass in the night. Paleobiology 6:383-396.

Greene, S. E., D. J. Bottjer, H. Hagdorn, and J.-P. Zonneveld. 2011. The Mesozoic return of Paleozoic faunal constituents. A decoupling of taxonomic and ecological dominance during the recovery from the end-Permian mass extinction. Palaeogeography, Palaeoclimatology, Palaeoecology 308:224-232.

Hiller, N., D. I. MacKinnon, and S. N. Nielsen. 2007. A review of the systematics, biogeography, and evolutionary relationships of Recent and fossil brachiopods of the Superfamily Kraussinoidea Dall, with descriptions of two new fossil species from New Zealand and Chile. Transactions of the Royal Society of Edinburgh (Earth and Environmental Science) 98:379-390.

Kiessling, W., C. Simpson, and M. Foote. 2010. Reefs as cradles of evolution and sources of biodiversity in the Phanerozoic. Science 327:196-198.
Kowalewski, M., M. G. Simões, M. Carroll, and D. L. Rodland. 2002. Abundant brachiopods on a tropical, upwelling-influenced shelf (southeast Brazilian Bight, South Atlantic). Palaios 17:277-286.

LaBarbera, M. 1981. The ecology of Mesozoic Gryphaea, Exogyra, and Ilymatogyra (Bivalvia. Mollusca) in a modern ocean. Paleobiology 7:510-526.

Lee, D. E. 1978. Aspects of the ecology and paleoecology of the Brachiopod Notosaria nigricans (Sowerby). Journal of the Royal Society of New Zealand 8:395-417.

Lee, D. L. 1991. Aspects of the ecology and distribution of the living Brachiopoda of New Zealand. Pp. 273-279 in D. I. MacKinnon, D. L. Lee, and J. D. Campbell, eds. Brachiopods through time. Proceedings of the 2nd International Brachiopod Congress. Balkema, Rotterdam.

Liow, L. H., T. Reitan, and P. G. Harnik. 2015. Ecological interactions on macroevolutionary time scales: clams and brachiopods are more than ships that pass in the night. Ecology Letters 18:1030-1039.

Manceñido, M. O., and C. D. Walley. 1979. Functional morphology and ontogenetic variation in the Callovian brachiopod Septirhynchia from Tunisia. Palaeontology 22:317-337.

Monarrez, P. M., M. Aberhan, and S. M. Holland. 2017. Regional and environmental variation in escalatory ecological trends during the Jurassic: a western Tethys hotspot for escalation? Paleobiology 43:569-586.

Noble, J. P. A., A. Logan, and G. R. Webb. 1976. The Recent Terebratulina community in the rocky subtidal zone of the Bay of Fundy, Canada. Lethaia 9:1-18.

Owen, E. F. 1978. The distribution of brachiopods within the Cenomanian of northwest and central Europe. Géologie Méditerranéenne 5:147-153.

Payne, J. L., N. A. Heim, M. L. Knope, and C. R. McClain. 2014. Metabolic dominance of bivalves predates brachiopod diversity decline by more than 150 million years. Proceedings of the Royal Society of London B 281:20133122-20133122.

Purser, B. H. 1969. Syn-sedimentary marine lithification of Middle Jurassic limestones in the Paris Basin. Sedimentology 12:205-230

Richardson, J. R. 1979. Pedicle structure of articulate brachiopods. Journal of the Royal Society of New Zealand 9:415-436.

Richardson, J. R. 1981a. Brachiopods and pedicles. Paleobiology 7:87-95.

Richardson, J. R. 1981b. Distribution and orientation of six articulate brachiopod species from New Zealand. New Zealand Journal of Zoology 8:189-196.

Richardson, J. R., and J. E. Watson. 1975. Form and function in a Recent free living brachiopod Magadina cumingi. Paleobiology 1:379-387.

Richardson, J. R., A. E. Aldridge, and I. D. Endersby. 2007. Post settlement behaviour of brachiopods on hard and soft substrates. New Zealand Journal of Zoology 34:43-49.

Rudwick, M. J. S. 1961. The anchorage of articulate brachiopods on soft substrata. Palaeontology 4:475-476.

Ruffell, A., and G. Wach. 1998. Firmgrounds-key surfaces in the recognition of parasequences in the Aptian Lower Greensand Group, Isle of Wight (southern England). Sedimentology 45:91-107.

Sepkoski, J. J. 1981. A factor analytic description of the Phanerozoic marine fossil record. Paleobiology 7:36-53.

Sepkoski, J. J., R. K. Bambach, and M. L. Droser. 1991. Secular changes in Phanerozoic event bedding and the biological overprint. Pp. 298-312 in G. Einsele, W. Ricken, and A. Seilacher, eds. Cycles and events in stratigraphy. Springer-Verlag, Berlin.

Smith, A. M., and C. S. Nelson. 2003. Effects of early sea-floor processes on the taphonomy of temperate shelf skeletal carbonate deposits. Earth-Science Reviews 63:1-31. 
Steele-Petrović, H. M. 1979. The physiological differences between articulate brachiopods and filter-feeding bivalves as a factor in the evolution of marine level-bottom communities. Palaeontology 22:101-134.

Stewart, I. R. 1981. Population structure of articulate brachiopod species from soft and hard substrates. New Zealand Journal of Zoology 8:197-207.

Surlyk, F. 1972. Morphological adaptations and population structures of the Danish chalk brachiopods (Maastrichtian, Upper Cretaceous). Biologiske Skrifter Det Kongelige Danske Videnskabernes Selskab 19:1-57.

Thayer, C. W. 1975. Morphologic adaptations of benthic invertebrates to soft substrata. Journal of Marine Research 33:177-189.

Thayer, C. W. 1979. Biological bulldozers and the evolution of marine benthic communities. Science 203:458-461.

Thayer, C. W. 1983. Sediment-mediated biological disturbance and the evolution of marine benthos. Pp. 479-625 in M. J. S. Tevesz and P. L. McCall, eds. Biotic interactions in recent and fossil benthic communities. Springer US, Boston.

Thayer, C. W. 1985. Brachiopods versus mussels: competition, predation, and palatability. Science 228:1527-1528.

Thomsen, E. 2005. Brachiopod-substrate relationships on the continental shelf of the Faroe Islands (NE Atlantic). BIOFAR Proceedings 2005:195-201.
Tomašových, A. 2006. Brachiopod and bivalve ecology in the Late Triassic (Alps, Austria): onshore-offshore replacements caused by variations in sediment and nutrient supply. Palaios 21:344-368.

Tomašových, A. 2008. Substrate exploitation and resistance to biotic disturbance in the brachiopod Terebratalia transversa and the bivalve Pododesmus macrochisma. Marine Ecology Progress Series 363:157-170.

Tomašových, A., and S. M. Kidwell. 2017. Nineteenth-century collapse of a benthic marine ecosystem on the open continental shelf. Proceedings of the Royal Society of London B 284:20170328.

Tyler, C. L., L. R. Leighton, S. J. Carlson, J. W. Huntley, and M. Kowalewski. 2013. Predation on modern and fossil brachiopods: assessing chemical defenses and palatability. Palaios 28:724-735.

Van Houten, F. B., and M. E. Purucker. 1985. On the origin of glauconitic and chamositic granules. Geo-Marine Letters 5:47-49.

Vermeij, G. J. 1977. The Mesozoic marine revolution: evidence from snails, predators and grazers. Paleobiology 3:245-258.

Vermeij, G. J. 2008. Escalation and its role in Jurassic biotic history. Palaeogeography, Palaeoclimatology, Palaeoecology 263:3-8.

Witman, J. D., and R. A. Cooper. 1983. Disturbance and contrasting patterns of population structure in the brachiopod Terebratulina septentrionalis (Couthouy) from two subtidal habitats. Journal of Experimental Marine Biology and Ecology 73:57-79. 